\title{
PERSPECTIVES OF FINANCIAL INTERMEDIATION AND FINANCIAL CONSULTANCY IN THE INSURANCE MARKET
}

\author{
[Perspektívy finančného sprostredkovania a finančného poradenstva \\ na poistnom trhu]
}

\author{
Anna Majtánová ${ }^{1}$, Andrea Snopková ${ }^{2}$ \\ ${ }^{1}$ Ekonomická univerzita Bratislava, Národohospodárska fakulta, Dolnozemská cesta 1, 85235 Bratislava 5 \\ Email: anna.majtanova@euba \\ ${ }^{2}$ Ekonomická univerzita Bratislava, Národohospodárska fakulta, Dolnozemská cesta 1, 85235 Bratislava 5 \\ Email: andrea.snopkova@euba.sk
}

\begin{abstract}
Financial intermediaries allow to search risks for insurance and thus they help to achieve greater expansion of trade for insurance companies and they help to choose high quality insurance to the ultimate clients based on their specific requests. In the current financial theory, but also in financial practice, it is paid attention to financial intermediation and financial consultancy. Aim of this paper is a theoretical definition of economic categories in these areas in a broader context, which are essential for the insurance practice. At the same time it is performed analysis of legal rules governing financial intermediation and financial consultancy in the Czech and Slovak Republics, their fundamental differences and specific advantages and disadvantages in their application.
\end{abstract}

Keywords: comparison, Czech Republic, financial consultancy, financial intermediation, legislative norms, Slovak Republic.

JEL classification: G22

Doručeno redakci: 28.6.2013; Recenzováno: 29.4.2014, 7.5.2014; Schváleno k publikování: 23.9.2014

\section{Úvod}

Poist'ovne v silnom konkurenčnom prostredí neustále hl'adajú a zdokonal'ujú distribúciu svojich produktov - poistenia - ku konečnému zákazníkovi. Vzhl'adom k tomu, že poistenie je pomerne komplexný produkt, ktorý môže byt' pre radu klientov dost' zložitý, a teda t'ažko pochopitel'ný, vyvinula sa historicky celá rada foriem distribúcie poistenia. Poistné produkty môžu poist'ovne distribuovat' priamo samé určitou formou alebo majú možnost' využit' služby profesionálnych finančných sprostredkovatel'ov a finančných poradcov. Využitie týchto služieb je výhodne nielen pre poist’ovne, ale vel'mi výhodné je aj pre ciel'ové skupiny klientov. Môžeme konštatovat', že na jednej strane finanční sprostredkovatelia umožňujú vyhl'adávat' riziká pre poistenie, a tým pomáhajú dosiahnut' poist'ovniam väčší rozmach obchodu a konečným zákazníkom, občanom, či podnikatel'ským subjektom pomáhajú vybrat' kvalitné poistenie podl'a ich osobitých potrieb a možností. V súčasnej finančnej teórii, ale aj vo finančnej praxi sa venuje vel'ká pozornost' finančnému sprostredkovaniu a $\mathrm{z}$ tohto dôvodu sme výskum realizovaný $\mathrm{v}$ rámci projektu ${ }^{1}$, ktorého je tento príspevok výstupom, zamerali sme sa práve na oblast' finančného sprostredkovania a finančného poradenstva. Ciel'om príspevku je teoretické vymedzenie ekonomických kategórií vo finančnom sprostredkovaní v širších súvislostiach, ktoré sú podstatné pre súčasnú poistnú prax. Nakol'ko tieto problémy rieši aj legislatíva upravujúca finančné trhy, d’alším ciel'om príspevku je komparácia legislatívnych noriem v Českej republike a v Slovenskej republike, vymedzenie ich zásadných rozdielov, výhod a nevýhod. Týmto ciel'om sme podriadili aj štruktúru príspevku.

\footnotetext{
${ }^{1}$ MŠ SR VEGA č. 1/0681/12 "Ekonomické prostredie a dynamika zmien v sektore poist’ovníctva" riešeného na Katedre poistovníctva NHF EU v Bratislave
} 


\section{Teoretické vymedzenie finančného sprostredkovania a finančného poradenstva}

Teoretickému vymedzeniu finančných sprostredkovatel'ov a finančných poradcov sa vo finančnej vede doteraz nevenovala zvýšená pozornost'. Vzhl'adom na aktuálnost' týchto ekonomických kategórií a činnosti, ktorými sa zaoberajú, je žiaduce poukázat' na definície niektorých teoretikov.

Autori Dennis W. Draper and James W. Hoag (1978) vo svojom diele Financial intermediation and the theory of agency konštatujú, že sprostredkovanie, a najmä finančné sprostredkovanie, je často pozorovaná skupina činností, pre ktoré odborná literatúra poskytuje len vel'mi málo definícii a aj napriek tomu, že sprostredkovatelia existujú takmer vo všetkých hlavných odvetviach hospodárstva, presná charakteristika sprostredkovatel'skej činnosti sa však doteraz neobjavila. Skôr akademická a praktická literatúra sa odvoláva na sprostredkovatel'ov, napríklad, všeobecne súhlasia, že tieto inštitúcie ako sú banky, poist’ovne a iné, sú sprostredkovatel'mi. Pri analýze týchto inštitúcií - finančných sprostredkovatel'ov, autori upozorňujú na skutočnost', že každý je zapojený do nejakého súboru z týchto troch činností (Draper, Hoag, 1978):

a) získavanie informácií o ekonomických subjektov,

b) spracovanie informácii o ekonomických subjektoch,

c) uspokojovanie finančných nárokov týchto ekonomických subjektov.

Ďalší autori, ktorí sa v 90-tych rokoch minulého storočia zaoberali otázkou finančných sprostredkovatel'ov boli Mayer a Vives (1993), rozoberajúci vo svojom diele Capital markets and financial intermediation aj potrebu finančných sprostredkovatel'ov vo vzt'ahu k bankám. „V tom čase sa začala venovat' pozornost' zmene úlohy finančných sprostredkovatel'ov. Toto sa objavuje $\mathrm{v}$ rovnakom čase ako finančné inovácie vedú niektorých pozorovatel'ov k poukázaniu, že existuje len malá budúcnost' finančného sprostredkovania vo financovaní vel'kých korporátnych aktivít. Integrácia finančných trhov v Európe a v tom čase hroziaci možný vznik jednotnej európskej meny vyvolali otázky o regulácii finančných trhov. Kládli si otázku: či väčšia konkurencia ohrozuje stabilitu bankového systému a či by sa mala regulácia bánk v budúcnosti zmenit?““

Thomas F. Cosimano (1996) vo svojom diele Intermediation sa zaoberal sprostredkovatel'mi, ktorí sa rozšírili do všetkých odvetví hospodárstva, ale je dôležité porozumiet', prečo l'udia používajú sprostredkovatel'ov a nevykonávajú priame obchody s kupujúcimi a predávajúcimi. Ekonomický systém prijal mnoho inštitúcií, ktoré sú prostredníkom medzi kupujúcimi a predávajúcimi. $\mathrm{Na}$ finančných trhoch sú banky, makléri a obchodníci, na komoditných trhoch sú maloobchodníci a supermarkety, na trhu s bývaním sú realitní agenti. Vzhl’adom k tomu, že sprostredkovatelia prenikli do celej ekonomiky, je dôležité pochopit', prečo l'udia používajú sprostredkovatel'ov a nevykonávajú priame obchody.

Odpoved' na tento problém hl'adali aj Cosimano a Baye (1990), ktorí skonštruovali model, pri ktorom sa kupujúci a predávajúci rozhodnú či sa podiel'at' na trhu ako priamy kupujúci alebo predávajúci, alebo nie. Baye a Cosimano poukázali na to, že existuje významná pravdepodobnost' neúspešného obchodu, ked' sú možné len priame obchody. V tomto prostredí sprostredkovatel' môže poskytnút' službu kupujúcim a predávajúcim. Stanovením ponuky a ceny, za ktorú predávajúci a kupujúci zaručujú obchod, sprostredkovatel' môže zvýšit' očakávaný zisk z obchodu. To znamená, že sprostredkovatel' poskytuje likviditu na hospodárske subjekty v zmysle Lippmana a Mccalla (1986). Ich práca (Cosimano a Baye) skúma vplyv sprostredkovatel'a na dobré obchodné podmienky všetkých zúčastnených strán 
v procese obchodovania. Podl'a ich zistení sa sprostredkovatel' zaväzuje vstúpit' do zodpovedajúceho procesu vtedy, ak jeho očakávané ekonomické zisky sú väčšie ako nula.

Osobité postavenie majú finanční sprostredkovatelia a finanční poradcovia v poistnom sektore, kde zastavajú významnú pozíciu ako prostredník medzi stranou ponuky a stranou dopytu na poistnom trhu. Podl'a Martiny Eckardt (2007) finanční sprostredkovatelia a poradcovia na jednej strane poskytujú distribučné a marketingové služby pre poist'ovne a na strane druhej ponúkajú informačné a poradenské služby pre spotrebitel'a. Finanční sprostredkovatelia a finanční poradcovia $\mathrm{v}$ poistnom sektore znižujú náklady na informovanie spotrebitel'ov o ich rizikových profilov, poistných potrebách a vhodných poistných produktoch, čím sa zjednoduší situáciu pre spotrebitel'a.

Vymedzenie ekonomických kategórií finančný sprostredkovatel' a finančný poradca sa legislatívne upravilo jednak v Slovenskej republike a jednak v Českej republike.

Zákon č. 38/2004 $\mathrm{Sb}^{2}{ }^{2}$ o pojištovacích zprostředkovatelích a samostatných likvidátorech pojistných událostí, ktorý je platný v Českej republike, definuje sprostredkovatel'skú činnost' v poist'ovníctve ako odbornú činnost' spočívajúcu v:

a) predkladaní návrhov na uzavretie poistných zmlúv alebo zaistných zmlúv,

b) vykonávanie prípravných prác smerujúcich $\mathrm{k}$ uzavretiu poistných alebo zaistných zmlúv,

c) uzatváranie poistných alebo zaistných zmlúv $\mathrm{v}$ mene a na účet poist'ovne alebo zaist'ovne, pre ktorú je táto činnost' vykonávaná alebo

d) pomoc pri správe poistenia a vybavovaní nárokov z poistných alebo zaistných zmlúv.

e) Poist’ovacím sprostredkovatel'om je podl'a tohto zákona právnická alebo fyzická osoba, ktorá za odplatu vykonáva sprostredkovatel'skú činnost' v poist'ovníctve.

Pri analýze definícií uvedených autorov konštatujeme, že aj súčasná legislatíva v Slovenskej republike, vychádza z týchto pojmov, presne zachytáva činností finančného sprostredkovania a finančného poradenstva, $\mathrm{k}$ čomu sa aj my prikláňame.

V Slovenskej republike zákon o finančnom sprostredkovaní a finančnom poradenstve č. 186/2009 Z. $\quad$ z. $^{3}$ s účinnost'ou od 1.1.2010 prináša nový spôsob regulácie sprostredkovatel'skej a poradenskej činnosti na celom finančnom trhu, nakol'ko zahŕňa aj oblasti finančného trhu, ktoré zatial' nie sú regulované. V Slovenskej republike zákon 186/2009 Z. z. definuje finančné sprostredkovanie a poradenstvo nasledovne:

Finančným sprostredkovaním je vykonávanie najmenej jednej z týchto činností:

a) predkladanie ponúk na uzavretie zmluvy o poskytnutí finančnej služby, uzavieranie zmluvy o poskytnutí finančnej služby a vykonávanie d'alších činností smerujúcich k uzavretiu alebo k zmene zmluvy o poskytnutí finančnej služby,

b) poskytovanie odbornej pomoci, informácií a odporúčaní klientovi na účely uzavretia, zmeny alebo ukončenia zmluvy o poskytnutí finančnej služby,

c) spolupráca pri správe zmluvy o poskytnutí finančnej služby, ak charakter finančnej služby takú spoluprácu umožňuje,

\footnotetext{
${ }^{2}$ Zákon č. 38/2004 Sb. zo 17. decembra 2003 o pojištovacích zprostředkovatelích a samostatných likvidátorech pojistných událostí a o změně živnostenského zákona (zákon o pojišt'ovacích zprostředkovatelích a likvidátorech pojistných událostí).

Zákon č. 186/2009 Z. z. z 24. apríla 2009 o finančnom sprostredkovaní a finančnom poradenstve a o zmene a doplnení niektorých zákonov.
} 
d) spolupráca pri vybavovaní nárokov a plnení plynúcich klientovi zo zmluvy o poskytnutí finančnej služby, najmä v súvislosti s udalost’ami rozhodujúcimi pre vznik takýchto nárokov, ak charakter finančnej služby takúto spoluprácu umožňuje.

Tento zákon definuje aj finančné poradenstvo ako poskytovanie odbornej pomoci, informácií, stanovísk, odporúčaní a osobných finančných plánov klientovi v súvislosti s jednou finančnou službou alebo viacerými finančnými službami vychádzajúce $\mathrm{z}$ nestrannej analýzy dostatočného počtu dostupných finančných služieb vrátane následného uzavierania alebo zmeny zmluvy o poskytnutí finančnej služby na žiadost' klienta, v jeho mene a na jeho účet. Finančným poradenstvom $\mathrm{v}$ sektore poistenia alebo zaistenia je aj zist'ovanie, hodnotenie a spracovávanie nestranných analýz poistného rizika.

Zákon č. 186/2009 Z. z. o finančnom sprostredkovaní a finančnom poradenstve preberá právne akty európskych spoločenstiev a Európskej únie, najmä Smernicu Európskeho parlamentu a Rady 2004/39/EC z 21. apríla 2004 o trhoch s finančnými nástrojmi, teda jednotlivé články sa zhodujú. Tak ako väčšina európskych smerníc, tak aj táto uprednostňuje obsah pred formou. Pred vstupom do Európskej únie bola požiadavka zo strany Európskej únie implementovat' túto smernicu do slovenskej legislatívy, ale nestalo sa tak. Slovenská republika patrila do tej skupiny štátov, ktoré s aproximáciou tejto smernice meškali a zákon č. 340/2005 Z. z. ${ }^{4}$ o sprostredkovaní poistenia a sprostredkovaní zaistenia nadobudol účinnost' až 1. septembra 2005. Táto zmena priniesla zásadné zmeny, ktoré na našom poistnom trhu dovtedy neexistovali.

Stručne poukážeme na hlavné rozdiely medzi súčasne platným zákonom č. 186/2009 Z. z. o finančnom sprostredkovaní a finančnom poradenstve a predchádzajúcim zákonom č. 340/2005 Z. z. o sprostredkovaní poistenia a sprostredkovaní zaistenia. Zákon č. 340/2005 Z. z. transponoval smernicu o sprostredkovaní v poist'ovníctve 2002/92/ES (IMD Intermediation Insurance Directive) v plnom rozsahu, a tak spĺn̆al všetky kritéria, ktoré Európska únia pre túto oblast' vyžadovala. Tento zákon upravoval výlučne sprostredkovanie v sektore poist'ovníctva na rozdiel od zákona č. 186/2009 Z. z. o finančnom sprostredkovaní a finančnom poradenstve, ktorý upravuje celý finančný trh, teda sektor poistenia a zaistenia, kapitálového trhu, doplnkového dôchodkového sporenia, prijímania vkladov a poskytovania úverov, čo znamená, že okrem smernice 2002/92/ES - IMD sa vychádzalo aj zo smernice 2004/39/EC (MIFID - Market in Financial Instrument).

Pôvodná legislatívna norma definovala sprostredkovatel'ov ako agentov a maklérov. Agenti konali v mene poist'ovne, t. z., že predávali produkty poist'ovní klientovi a makléri konali na základe zmluvy s klientom, t. z., že kupovali produkty poist'ovní pre klienta. Podl'a zákona č. 186/2009 Z. z. sú sprostredkovatel'mi iba agenti, ktorí konajú na základe zmluvy s poist'ovňou a teda nad'alej predávajú klientovi produkty tých poist'ovní, s ktorými majú zmluvu. Finančný poradca koná na základe zmluvy s klientom, nakupuje produkty pre klienta, ale už nie sú vedení ako sprostredkovatelia. Znamená to, že nový zákon zaviedol dve odlišné skupiny podnikatel'ov, ktorí sa zaoberajú vel'mi podobnou činnost'ou, ale rozdelil ich názvom aj postavením podl'a toho, na ktorej strane zmluvných partnerov pri finančných službách sa nachádzajú.

Zákon o finančnom sprostredkovaní a finančnom poradenstve č. 186/2009 Z. z. na jednej strane priniesol nový spôsob regulácie sprostredkovatel'skej a poradenskej činnosti na celom

\footnotetext{
${ }^{4}$ Zákon č. 340/2005 Z. z. z 23. júna 2005 o sprostredkovaní poistenia a sprostredkovaní zaistenia a o zmene a doplnení niektorých zákonov.
} 
finančnom trhu, nakol'ko zahŕňa aj oblasti finančného trhu, ktoré zatial' nie sú regulované. Hlavným účelom tohto zákona bolo vytvorit' právny rámec, ktorý bude účinný aj pri ochrane práv spotrebitel'ov na finančnom trhu. $\mathrm{Na}$ druhej strane zákon však zredukoval rady finančných agentov v Slovenskej republike, kým na konci roka 2010 ich pôsobilo vyše 26 tisíc, v roku 2012 ich bolo už len $14918 .^{5}$

\section{Komparácia finančného sprostredkovania Českej republiky a Slovenskej republiky}

Profesia poist'ovacieho makléra našla svoje uplatnenie v konkurenčnom prostredí, preto v Českej republike sa rozšírila až po páde monopolu Státní pojišt'ovny v procese transformácie po roku 1989. Zákon o poist'ovníctve z roku 1991 umožnil činnost' maklérskych spoločností na československom poistnom trhu, kde najprv pôsobili prevažne zahraničné firmy, pretože českých maklérskych spoločností bolo len vel'mi málo. V marci roku 1994 bola založená Asociácia českých poist’ovacích maklérov. K zakladatel'om asociácie patrili aj štyri české firmy. Asociácia mala prísne kritéria na prijímanie nových členov a výsledkom bolo dlhodobo uzavretá spoločnost'. Z tohto dôvodu vznikali aj iné spolky ako Komora poist'ovacích maklérov, ktorá združovala práve tie spoločnosti, ktoré nespíňali kritériá členstva v asociácii. Dňa 1.1.2005 sa asociácie zlúčili do spoločného združenia pod názvom Asociácia českých poist'ovacích maklérov. Na českom poistnom trhu pôsobia v súčasnosti dve asociácie, ktoré pokrývajú finančných sprostredkovatel'ov. K rozdeleniu asociácie na dve došlo vtedy, ked’ sa prejavili rozdielne názory ani nie tak na fungovanie trhu, ale skôr v pohl'ade na fungovanie asociácie (Škriniar, 2010). Obidve si však navzájom nekonkurujú a majú medzi sebou dohodu o spolupráci.

V zákone č. 363/1999 Sb. ${ }^{6}$ o pojišt'ovnictví bol zavedený a definovaný pojem poist’ovací agent a poist'ovací a zaist'ovací maklér, ktorých hlavnou podmienkou výkonu týchto činností bola predovšetkým bezúhonnost' a poistenie profesijnej zodpovednosti. Týmto zákonom však neboli splnené všetky požiadavky smerníc Európskej únie a chýbali predovšetkým kvalifikačné požiadavky.

Základnou činnost'ou poist'ovacieho sprostredkovatel'a je nájst' optimálneho poist'ovatel'a pre daného zákazníka. Predstavuje medzičlánok, ktorý ul'ahčuje styk klienta s poist'ovňou. V podmienkach Českej republiky je poist'ovací sprostredkovatel' charakterizovaný ako osoba (fyzická alebo právnická), ktorá za úplatu poskytuje sprostredkovatel'skú činnost' v oblasti poist'ovníctva. Všetci sprostredkovatelia musia byt' zapísaní v registri a plnit' podmienky dôveryhodnosti a súčasne musia splnit’ odborné predpoklady. (Ducháčková, 2005)

Predaj poistenia a finančné poradenstvo $\mathrm{v}$ tejto oblasti upravujú dva zákonné predpisy: Zákon o poišt'ovnictve č. 277/2009 Sb. $^{7}$ (účinný od 1.1.2010) a Zákon o pojištovacích zprostředkovatelích a samostatných likvidátorech pojistných událostí č. 38/2004 Sb.

Makléri vnímajú Zákon o pojišt’ovacích zprostředkovatelích a samostatných likvidátorech pojistných událostí ako negatívny fakt, ktorý povol'uje vykonávanie činnosti iba v postavení, ked' bol sprostredkovatel' zaregistrovaný. Oproti predošlému stavu to znamená, že osoby vykonávajúce agentskú a maklérsku činnost' zároveň, sa budú musiet' registrovat' dvakrát, a to napriek tomu, že požiadavky na makléra sú vyššie a automaticky $v$ sebe zahrňujú

\footnotetext{
${ }^{5}$ KAČALKA, L’uboslav. AFISP: Počet agentov sa znížil o 42\%, tí čo ostali, sú dobre pripravení. [online]. [citované 2013-04-09]. 2012. Dostupné na internete: http://www.investujeme.sk/afisp-pocet-agentov-sa-znizilo-42-ti-co-ostali-su-dobre-pripraveni/.

${ }^{6}$ Zákon č. 363/1999 Sb. o pojišt’ovnictví a o změně některých souvisejících zákonů ze dne 21. decembra 1999.

${ }^{7}$ Zákon č. 277/2009 Sb. o pojišt’ovnictví a o změně některých souvisejících zákonů zo dňa 22. júl 2009.
} 
aj požiadavky na agenta. Vel'ký vplyv môže mat' aj zvýšenie povinného poistenia zodpovednosti za škodu. Predtým českí makléri mali povinnost' ručit' do výšky 5 miliónov Kč, ale zákon zvýšil túto sumu až na 1,5 mil. EUR. Menší makléri s najväčšou pravdepodobnost'ou mohli zaniknút' alebo sa začali spájat' alebo transformovat' na agentov.

Český trh sprostredkovania je v niektorých kritériách pred slovenským, v iných naopak slovenský predbehol ten český. Za vel'kú výhodu slovenského sa považuje, že z právneho hl'adiska je pokrytá všetka distribúcia finančných produktov. V Českej republike sa o to už snažia už dlhšie obdobie. V súčasnej dobe Ministerstvo financií Českej republiky už pripravilo návrh zákona, ktorý by sa mal prijat' v podobe nového zákona. V rámci Európskej únie sa tiež pripravovali určité zmeny, a preto Česká republika čakala na to, čo prinesú regulácie Európskej únie. Pre porovnanie Slovenská republika prijala zákon upravujúci túto oblast’ ako jedna z prvých krajín Európskej únie.

V Českej republike neoddel'ujú sprostredkovanie od poradenstva. Je len vel'mi tenká hranica medzi radou a poradenstvom, a preto je ich t’ažko oddelit'. Klient čaká radu aj ked' príde za sprostredkovatel'om. Poradenstvo pozostáva vlastne zo zostavenia finančnej analýzy klientovi, a tým zistí jeho potreby a snaží sa ich uspokojit'. V českom zákone je zatial' definované len investičné poradenstvo.

V súčasnej dobe sa vel'ká pozornost' v Českej republike venuje novele zákona č. 38/2004, ktorá prináša rozsiahle zmeny doterajšej právnej úpravy. Kontroverzná novela zákona č. 38/2004 Sb. o pojišt'ovacích zprostředkovatelích a samostatných likvidátorech prežila pokus o zamietnutie, prešla prvým čítaním a Rozpočtový výbor ju prejedná v predlženej lehote 80 dní. ${ }^{8}$ Táto novela nie je podporovaná zo strany poist'ovní a sprostredkovatel'ov, ktorí upozorňujú na jej závažné nevýhody

Do registra poistných sprostredkovatel'ov a samostatných likvidátorov poistných udalostí, ktorý vedie Česká národná banka bolo zapísaných 20143 poist'ovacích sprostredkovatel'ov všetkých kategórii. V súvislosti s touto agendou zaist’uje Česká národná banka odborné skúšky poist'ovacieho agenta a poist'ovacieho makléra, ktorých účelom je overenie odbornej spôsobilosti. ${ }^{9}$

Prehl'adnou formou (tabul'ka 1) analyzujeme zmeny vo vybraných oblastiach finančného sprostredkovania a finančného poradenstva v Slovenskej republike v komparácií s Českou republikou a to jednak s platnou legislatívou a jednak s novelou zákona s pripravovanými zásadnými zmenami.

\footnotetext{
${ }^{8}$ Opojištění.cz. 2013. Novela zákona 38 prošla prvním čtením. [online]. [cit. 2013-02-23]. 2013. Dostupné na internete: http://www.opojisteni.cz/ekonomika/novela-zakona-38-prosla-prvnim-ctenim/

${ }^{9}$ Spracované na základe: ČNB. 2011. Výroční zpráva 2010. [online]. [cit.2013-02-23]. 2011. Dostupné na internete: http://www.cnb.cz/miranda2/export/sites/www.cnb.cz/cs/o_cnb/hospodareni/ vyrocni_zpravy/download/vyrocni_zprava_2010.pdf. ISBN 978-80-87225-29-5.
} 
Tabul'ka 1: Komparácia legislatívnych noriem o finančnom sprostredkovaní a finančnom poradenstve v Slovenskej republike a Českej republike

\begin{tabular}{|c|c|c|c|}
\hline Názov právnej normy & 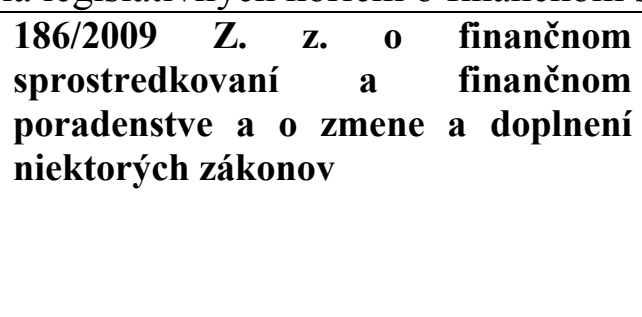 & 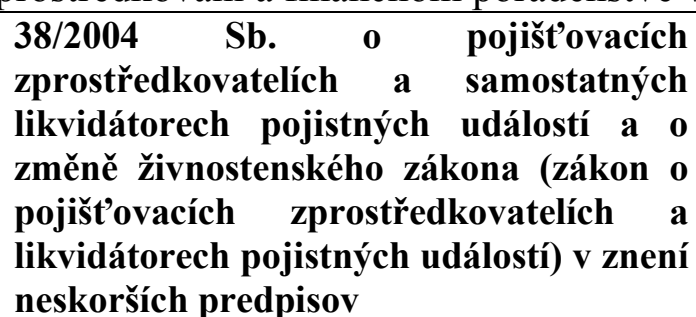 & $\begin{array}{l}\text { Novela zákona } 38 / 2004 \text { „o nabízení a } \\
\text { zprostředkování pojištění a zajištění, } \\
\text { samostatných likvidátorech } \\
\text { pojistných } \\
\text { událostí a o změně živnostenského } \\
\text { zákona (zákon } \\
\text { v pojišt’ovnictví)“ }\end{array}$ \\
\hline Aké sektory upravuje & $\begin{array}{l}\text { 1. poistenie a zaistenie } \\
\text { 2. kapitálový trh } \\
\text { 3. doplnkové dôchodkové sporenie } \\
\text { 4. prijímanie vkladov } \\
\text { 5. poskytovanie úverov }\end{array}$ & poistenie a zaistenie & poistenie a zaistenie \\
\hline Kategorizácia & $\begin{array}{l}\text { Finančný agent: } \\
\text { a) samostatný finančný agent, } \\
\text { b) viazaný finančný agent, } \\
\text { c) podriadený finančný agent } \\
\text { Finančný poradca } \\
\text { Finančný sprostredkovatel' z iného } \\
\text { členského štátu v sektore poistenia } \\
\text { alebo zaistenia } \\
\text { Viazaný investičný agent }\end{array}$ & $\begin{array}{l}\text { Poist'ovací sprostredkovatel': } \\
\text { a) viazaný poistovací sprostredkovatel' } \\
\text { b) podriadený poistovací sprostredkovatel' } \\
\text { c) poist'ovací agent } \\
\text { d) výhradný poist'ovací agent } \\
\text { e) poist'ovací maklér } \\
\text { Poist'ovací sprostredkovatel', ktorého } \\
\text { domovským štátom nie je Česká republika } \\
\text { Samostatný likvidátor poistných udalosti }\end{array}$ & $\begin{array}{l}\text { Poist'ovací sprostredkovatel': } \\
\text { a) viazaný zástupca } \\
\text { b) samostatný sprostredkovatel' } \\
\text { Poist'ovací sprostredkovatel' s domovským } \\
\text { členským štátom iným ako je Česká } \\
\text { republika } \\
\text { Samostatný likvidátor poistných udalosti }\end{array}$ \\
\hline $\begin{array}{l}\text { Zodpovednost' } \\
\text { škodu }\end{array}$ & $\begin{array}{l}\text { Limit poistného plnenia pre poistné } \\
\text { krytie musí byt' najmenej } 100 \text { 000 eur } \\
\text { na každú poistnú udalost' a najmenej } \\
150000 \text { eur úhrnom pre všetky poistné } \\
\text { udalosti vzniknuté } \mathrm{V} \text { jednom } \\
\text { kalendárnom roku. Ak ide o sektor }\end{array}$ & 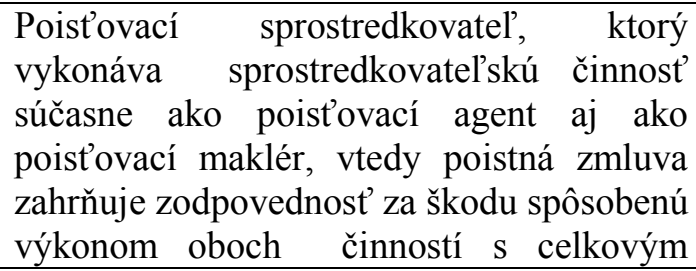 & $\begin{array}{l}\text { Samostatný sprostredkovatel' musí byt' po } \\
\text { celou dobu poistený na celom území } \\
\text { Európskeho hospodárskeho priestoru, } \\
\text { s limitom poistného plnenia najmenej vo } \\
\text { výške } 1200000 \text { eur na každú poistnú } \\
\text { udalost' a v prípade súbehu viac poistných }\end{array}$ \\
\hline
\end{tabular}




\begin{tabular}{|c|c|c|c|}
\hline & $\begin{array}{l}\text { poistenia alebo zaistenia, poistná } \\
\text { zmluva musí mat' platnost' aj na území } \\
\text { iných členských štátov a výška } \\
\text { poistného krytia v poistnej zmluve musí } \\
\text { byt' najmenej } 1120200 \text { eur na každú } \\
\text { poistnú udalost' a najmenej } 1680300 \\
\text { eur úhrnom pre všetky poistné udalosti } \\
\text { vzniknuté v jednom kalendárnom roku. }\end{array}$ & $\begin{array}{l}\text { limitom poistného plnenia najmenej vo } \\
\text { výške } 1200000 \text { eur na každú poistnú } \\
\text { udalost', v prípade súbehu viac poistných } \\
\text { udalostí v jednom roku najmenej vo výške } \\
\text { zodpovedajúcej hodnote } 1700000 \text { eur. }\end{array}$ & $\begin{array}{l}\text { udalostí v jednom roku najmenej vo výške } \\
1700000 \text { eur. To neplatí, ked' samostatný } \\
\text { sprostredkovatel' má písomné zmluvy na } \\
\text { účet jednej alebo viacero poist'ovní alebo } \\
\text { zaist'ovní a každá z nich sa zaviaže } \\
\begin{array}{l}\text { prevziat' zodpovednost' za škody } \\
\text { spôsobené jeho činnostou. }\end{array}\end{array}$ \\
\hline Dohl'ad & Národná banka Slovenska & Česká národná banka & Česká národná banka \\
\hline $\begin{array}{lc}\text { Náklady spojené } & \text { so } \\
\text { sprostredkovaním } & \text { a } \\
\text { poradenstvom } & - \\
\text { provízie, odmeny } & \end{array}$ & $\begin{array}{l}\text { Finančný agent musí svojho klienta } \\
\text { informovat', akú odmenu od finančnej } \\
\text { inštitúcie získa za sprostredkovanie } \\
\text { produktu. Finančný poradca nesmie } \\
\text { od finančnej inštitúcie prijat' akékol'vek } \\
\text { peňažné plnenie alebo nepeňažné } \\
\text { plnenie s výnimkou plnenia od klienta. }\end{array}$ & Neupravuje podmienky. & $\begin{array}{l}\text { Prvý návrh novely zákona: Výška odmeny, } \\
\text { ktorú poistitel' za zjednanú poistnú zmluvu } \\
\text { o rezervotvornom životnom poistení hradí } \\
\text { poistovacím sprostredkovatel'om, nesmie } \\
\text { prekročit' dvojnásobok dohodnutého } \\
\text { mesačného poistného alebo ekvivalent } \\
\text { jednorazového poistného za poistné } \\
\text { obdobie, najviac však } 4000 \text { korún. } \\
\text { Nový návrh novely: provízie nie sú } \\
\text { regulované. Zákaz prijímania provízií v } \\
\text { rámci maklérskej činnosti, ale nad'alej je } \\
\text { možný súbeh maklérskej a agentskej } \\
\text { činnosti. Obmedzenie použivania pojmu } \\
\text { poist'ovací maklér. }\end{array}$ \\
\hline $\begin{array}{l}\text { Informovanost' } \\
\text { klienta }\end{array}$ & $\begin{array}{l}\text { Povinnost' zverejňovania klúččých } \\
\text { informácií. }\end{array}$ & $\begin{array}{l}\text { Nie je nutnost' zverejňovania informácií } \\
\text { (určité informácie len na vyžiadanie } \\
\text { klienta) }\end{array}$ & $\begin{array}{l}\text { Povinnost' } \\
\text { informácií. }\end{array}$ \\
\hline
\end{tabular}

Zdroj: Vlastné spracovanie na základe zákonov č. 186/2009 Z. z. o finančnom sprostredkovaní a finančnom poradenstve a o zmene a doplnení niektorých zákonov, č. 38/2004 Sb. o pojištovacích zprostředkovatelích a samostatných likvidátorech pojistných událostí a o změně živnostenského zákona (zákon o pojištovacích zprostředkovatelích a likvidátorech pojistných událostí) v znení neskorších predpisov a novely zákona 38/2004 „o nabízení a zprostředkování pojištění a zajištění, samostatných likvidátorech pojistných událostí a o změně živnostenského zákona (zákon o distribuci v pojištovnictví)“ 
Na základe realizovanej komparácie možno pozorovat' mnohé odlišné, ale aj zhodné znaky legislatívy v Českej republike a v Slovenskej republike.

Hlavným ciel’om novely zákona v Českej republike je väčšia ochrana spotrebitel’a, pričom je potrebné urobit' zmeny $\mathrm{v}$ distribúcii poistenia $\mathrm{v}$ jednotlivých kategóriách poist'ovacích sprostredkovatel'ov a spôsobe ich registrácie. Týmto zmenám by mali byt' podriadené aj požiadavky na odbornú spôsobilost', ktoré distribuujú poistenie, ale aj pravidlá, ktoré musia dodržiavat' pri rokovaní so zákazníkom.

Novela zákona d'alej navrhuje zmenit' súčasných pät' kategórií sprostredkovatel'ov len na dve. Viazaného a podriadeného poist'ovacieho sprostredkovatel'a a výhradného poist'ovacieho agenta majú záujem zlúčit' do jednej kategórie - viazaný zástupca. Poist'ovací agent a poist'ovací maklér by predstavovali druhú kategóriu - samostatný sprostredkovatel'. Dôvodom je zjednodušenie a sprehl'adnenie situácie na trhu a zjednodušenie situácie aj pre klienta, pre ktorého je tol'ko kategórii mätúcich. Tieto pozície sa od seba budú odlišovat' tým, či daná osoba nesie zodpovednost' za svoju činnost' sama alebo túto zodpovednost' preberá iný subjekt a platí pritom, že každá osoba bude na trhu oprávnená pôsobit' len v jednej z týchto možnosti. Viazaný zástupca bude pracovat' pre jeden subjekt, ktorý za jeho činnost' bude plne zodpovedat' a samostatný sprostredkovatel' bude sprostredkovávat' poistenie alebo zaistenie na účet jednej alebo viacerých spoločností alebo na základe zmluvy so zákazníkom. ${ }^{10}$ Pokial' bude pracovat' výlučne na základe tejto zmluvy, môže použit' označenie maklér, pričom sám zodpovedá za škodu spôsobenú pri prevádzkovaní tejto činnosti. Pokial' samostatný sprostredkovatel' bude pracovat' so zákazníkom na základe zmluvy, nemôže súčasne ohl'adom poistenia, ktoré je predmetom zmluvy, jednat' v mene a na účet poist'ovne. ${ }^{11}$ Maklér je viazaný obsahom zmluvy uzatvorenej so záujemcom, ale môže ku sprostredkovaniu pristupovat' aj agentsky, teda na základe zmluvy s poist'ovňou, preto jeho motivácia vybrat' správny produkt sa tým mení a navyše žije z dvoch províznych schém a klient o jeho väzbe na konkrétnu poist'ovňu nevie. ${ }^{12}$ V Slovenskej republike sú podl'a súčasne platnej legislatívy tri kategórie finančných sprostredkovatel'ov.

Vel'kým rozdielom medzi Českou a Slovenskou republikou je v sektoroch, ktoré jednotlivé zákony upravujú. Zákon č. 186/2009 Z. z. o finančnom sprostredkovaní a finančnom poradenstve upravuje pät' sektorov, ktoré predchádzajúci zákon upravujúci finančné sprostredkovanie na území Slovenskej republiky neobsahoval. Zákon reguluje finančné sprostredkovanie a poradenstvo $\mathrm{v}$ sektoroch poistenia a zaistenia (pred 1.1.2010 regulované zákonom č. 340/2005 Z. z. o sprostredkovaní poistenia a sprostredkovaní zaistenia), kapitálového trhu (pred 1.1.2010 upravené v $§ \S 61$ a 61a zákona č. 566/2001 Z. z. o cenných papieroch), doplnkového dôchodkového sporenia ( $\S \S 68$ až 68c zákona č. 650/2004 Z. z. o doplnkovom dôchodkovom sporení), prijímania vkladov podl'a zákona č. 483/2001 Z. z.

${ }^{10}$ ČAP. 2012. Česká asociace pojištoven: Jaké změny čekají zprostředkovatele? [online]. [cit. 2013-02-23]. 2012. Dostupné na internete: http://www.opojisteni.cz/ekonomika/ceska-asociace-pojistoven-jake-zmenycekaji-zprostredkovatele/.

${ }^{11}$ C̆AP. 2012. Česká asociace pojištoven: Jaké změny čekají zprostředkovatele? [online]. [cit. 2013-02-23]. 2012. Dostupné na internete: http://www.opojisteni.cz/ekonomika/ceska-asociace-pojistoven-jake-zmeny-cekajizprostredkovatele/.

${ }^{12}$ KOMISE PRO HODNOCENÍ DOPADU REGULACE. 2012. Stanovisko komise pro hodnoceni dopadi regulace $k$ návrhu zákona kterým se méní zákon č. 38/2004 Sb., o pojišstovacích zprostředkovatelích a samostatných likvidátorech pojistných události a o změně živnostenského zákona (zákon o pojištovacích zprostředkovatelích a likvidátorech pojistných událostí), ve znění pozdějšich předpisů, a dalši souvisejíci zákony. [online]. [cit. 2013-03-10]. Praha: 2012. Dostupné na internete: http://www.vlada.cz/assets/ppov/lrv/ria/databaze/781_11_MF-Navrh-stanoviska-k-zakonu-o-pojistovacichzprostredkovatelich.pdf 
o bankách a zákona č. 310/1992 Zb. o stavebnom sporení (sprostredkovanie a poradenstvo $\mathrm{v}$ tejto oblasti nie je pred 1.1.2010 osobitne regulované) a poskytovania úverov a spotrebitel'ských úverov podl'a zákona č. 258/2001 Z. z. o spotrebitel'ských úveroch a podl'a zákona č. 483/2001 Z. z. o bankách a zákona č. 310/1992 Zb. o stavebnom sporení (sprostredkovanie a poradenstvo $\mathrm{v}$ tejto oblasti taktiež nie je pred 1.1.2010 osobitne regulované). ${ }^{13} \mathrm{Na}$ rozdiel od Slovenskej republiky v Českej republike zákon upravuje len sektor poistenia a zaistenia.

Dôležitým predpokladom, aby boli poskytované služby zákazníkom na čo najvyššej úrovni je odborná spôsobilost'. Systém by mal byt' nastavený tak, aby predstavoval určitú mieru garancie preukázatel'nej úrovne získaných znalostí v danej oblasti, a to u všetkých osôb, ktoré dojednávajú poistenie so zákazníkmi. Zásadnou zmenou v oblasti preukazovania odbornosti by mala byt', že sa bude zákon dotýkat' všetkých osôb, vrátane zamestnancov poist'ovni.

V súčasnosti existujú v Českej republike tri kvalifikačné stupne, a to základný kvalifikačný stupeň, ktorý musí spĺn̆at' viazaný poist'ovací sprostredkovatel', výhradný poist'ovací agent, podriadený poistovací sprostredkovatel', samostatný likvidátor poistných udalosti a zamestnanci poist'ovni, stredný kvalifikačný stupeň je povinný pre poist'ovacieho agenta a musí spĺn̆at' aj najmenej dvojročnú odbornú prax a vyšší kvalifikačný stupeň musí spíňat' poist'ovací maklér spolu so štvorročnou odbornou praxou. Po piatich rokoch musia všetci sprostredkovatelia absolvovat' doškol'ovací kurz.

Novela zákona už s kvalifikačnými stupňami a doškol'ovacími kurzami nepočíta. Poist’ovací sprostredkovatel' bude musiet' každých pät' rokov zložit' odbornú skúšku a všeobecné znalosti sa budú preukazovat' vysvedčením o maturitnej skúške, odborné znalosti potom osvedčením o odbornej skúške zloženej u akreditovanej osoby. ${ }^{14}$ Úprava obsahu skúšky nie je ešte obsahom novely a ani sa k tomu neviedli rokovania a nie je vydaný žiaden právny predpis.

V Slovenskej republike je situácia odlišná od návrhu novely v Českej republike. Po prijatí zákona sa kvalitou zaoberá aj Národná banka Slovenska. Odbornou spôsobilost'ou na účely tohto zákona sú teoretické znalosti a praktické schopnosti fyzických osôb vykonávat' finančné sprostredkovanie alebo finančné poradenstvo riadne a na dostatočnej odbornej úrovni. ${ }^{15}$

Znamená to, že požiadavky pre jednotlivé stupne odbornej spôsobilosti v Slovenskej republike, ktoré vyplývajú z platnej legislatívy sú pomerne náročné. Zákon č. 186/2009 Z. z. o finančnom sprostredkovaní a finančnom poradenstve ustanovuje tieto štyri stupne odbornej spôsobilosti, kde každý stupeň počíta s tým, že uchádzači majú ukončené minimálne stredné odborné vzdelanie a v ostatných požiadavkách sa značne odlišujú. V základnom stupni odbornej spôsobilosti musia mat' uchádzači aj absolvované osobitné finančné vzdelávanie pre každý sektor, v ktorom je osoba oprávnená vykonávat' finančné sprostredkovanie. V strednom stupni odbornej spôsobilosti sú dve možností: ukončené stredné odborné vzdelanie, dvojročná odborná prax $\mathrm{v}$ príslušnom sektore, úspešne vykonaná odborná skúška a absolvovanie

\footnotetext{
${ }^{13}$ NBS. 2011. Dohlad nad finančným sprostredkovaním a finančným poradenstvom. [online]. [cit. 2013-05-12]. 2011. Dostupné na internete: http://www.nbs.sk/sk/dohlad-nad-financnym-trhom/dohlad-nad-financnymsprostredkovanim-a-financnym-poradenstvom.

14 ČAP. 2012. Česká asociace pojištoven: Jaké změny čekají zprostředkovatele? [online]. [cit. 2013-02-25]. 2012. Dostupné na internete: http://www.opojisteni.cz/ekonomika/ceska-asociace-pojistoven-jake-zmenycekaji-zprostredkovatele/.

${ }^{15}$ Zákon č. 186/2009 Z. z. z 24. apríla 2009 o finančnom sprostredkovaní a finančnom poradenstve a o zmene a doplnení niektorých zákonov
} 
osobitného finančného vzdelávania pre každý sektor, v ktorom je osoba oprávnená vykonávat' finančné sprostredkovanie alebo ukončené vysokoškolské vzdelanie a úspešne vykonanie odbornej skúšky. Vo vyššom stupni odbornej spôsobilosti sú dokonca tri alternatívy: ukončené stredné odborné vzdelanie, pät'ročná odborná prax v príslušnom sektore, úspešne vykonaná odborná skúška a absolvovanie osobitného finančného vzdelávania pre každý sektor, v ktorom je osoba oprávnená vykonávat' finančné sprostredkovanie, alebo ukončené úplné stredné všeobecné vzdelanie alebo úplné stredné odborné vzdelanie, trojročná odborná prax v príslušnom sektore, úspešne vykonaná odborná skúška a absolvovanie osobitného finančného vzdelávania pre každý sektor, v ktorom je osoba oprávnená vykonávat' finančné sprostredkovanie, alebo ukončené vysokoškolské vzdelanie, trojročná odborná prax v príslušnom sektore a úspešne vykonaná odborná skúška. Pre najvyšší stupeň odbornej spôsobilosti musia uchádzači splńat' bud' úplné stredné všeobecné vzdelanie alebo úplné stredné odborné vzdelanie, desat'ročná odborná prax v príslušnom sektore, úspešne vykonaná odborná skúška s certifikátom a absolvovanie osobitného finančného vzdelávania pre každý sektor, v ktorom je osoba oprávnená vykonávat' finančné poradenstvo, alebo vysokoškolské vzdelanie, pätročná odborná prax v príslušnom sektore a úspešne vykonaná odborná skúška s certifikátom. ${ }^{16}$

Viazaný finančný agent a jeho zamestnanci musia spĺn̆at' požiadavky pre základný stupeň odbornej spôsobilosti, podriadený finančný agent ${ }^{17}$ a zamestnanci samostatného finančného agenta zase musia splńat' požiadavky pre stredný stupeň odbornej spôsobilosti, samostatný finančný agent a zamestnanci finančného poradcu musia splńnat' požiadavky pre vyšší stupeň odbornej spôsobilosti a finančný poradca musí spĺn̆at' požiadavky pre najvyšší stupeň odbornej spôsobilosti. ${ }^{18}$

Súčasne platná právna úprava u niektorých sprostredkovatel'ských kategórií, v rámci ktorých dochádza k prenosu zodpovednosti na „,nadriadený subjekt“ (u podriadeného poist'ovacieho sprostredkovatel'a a viazaného poist'ovacieho sprostredkovatel'a) pripúšt'a možnost' zastupovat' viacej ako jednu osobu, a tým dochádza $z$ hl'adiska transparentnosti činnosti sprostredkovatel'a k nežiaducemu deleniu zodpovednosti za činnost' „viazaného“ zástupcu a prípadnej škody im spôsobenej medzi viac zastúpených osôb. ${ }^{19}$ Smernica upravuje len zmluvne viazaného sprostredkovatel'a poistenia.

Návrh predpokladá, aby viazaný zástupca mohol sprostredkovávat' poistenie len pre jednu poist'ovňu alebo samostatného sprostredkovatel'a. Tento návrh je nevýhodný pre nekompozitné $^{20}$ poist'ovne existujúce $\mathrm{v}$ rámci jednej finančnej skupiny, pretože viazaní zástupcovia tejto spoločnosti by nemohli sprostredkovávat' celú škálu poistných

\footnotetext{
16 Všetky stupne odbornej spôsobilosti sú spracované na základe zákona č. 186/2009 Z. z. o finančnom sprostredkovaní a finančnom poradenstve a o zmene a doplnení niektorých zákonov

17 Ak podriadený finančný agent vykonáva finančné sprostredkovanie len v jednom sektore, počas jedného roka odo dňa prvého zápisu do príslušného zoznamu v príslušnom podregistri podl'a $§ 13$ musí spĺn̆at' požiadavky pre základný stupeň odbornej spôsobilosti

${ }^{18}$ NBS. 2011. Kategórie finančných agentov a stupne odbornej spôsobilosti. [online]. [citované 2013-06-10]. 2011. Dostupné na: http://www.nbs.sk/sk/dohlad-nad-financnym-trhom/dohlad-nad-financnymsprostredkovanim-a-financnym-poradenstvom/odborna-sposobilost/kategorie-financnych-agentov-a-stupneodbornej-sposobilosti.

${ }^{19}$ MINISTERSTVO FINANCÍ ČR. 2012. Di̊vodová zpráva: Závěrečná zpráva z hodnocení dopadů regulace podle obecných zásad (RIA). [online]. [citované 2013-05-13]. 2012. Dostupné na: http://www.vlada.cz/assets/ppov/lrv/ria/databaze/Zaverecna-zprava-RIA_2.doc.

${ }^{20}$ Kompozitné poist’ovne = univerzálne, poist'ovne, ktoré podnikajú produkty v oboch poistných odvetviach súčasne
} 
produktov skupiny. Dobrým a vhodnejším riešením by mohlo byt' riešenie princípom jednotnej zodpovednosti zvlášt' pre oblast'životného a zvlášt' pre oblast' neživotného poistenia. $^{21}$

Poskytovanie informácii, hlavne zrozumitel’ných a jasných, je považované za kl'účový problém nielen poistného sektora. Novela si vyžaduje pomerne mnoho informácii, ku ktorým sa má zákazník dostat' pred podpisom zmluvy. Problémom je, že nekonkretizuje spôsob v akom by mali byt' dané informácie podávané. Súčasná legislatíva neudáva povinnost' zverejňovania informácií, len v prípade, že si klient určité informácie vyžiada. Zo strany sprostredkovatel'ov je to brané len ako formalita a zákazníkovi tak neumožní adekvátne rozhodovanie. Preto, podl'a nášho názoru, by bolo vhodným riešením, zapracovat' do nového zákona, povinnost' zverejňovania určitých vybraných a pre zákazníka dôležitých informácii $\mathrm{v}$ určitej štandardizovanej podobe.

V prípade žiadosti o zápis do registra je potrebné zaplatit' správny poplatok. Jeho výška je upravená v zákone č. 634/2004 Sb. o správních poplatcích ve znění pozdějších předpisů a predstavuje pre samostatného sprostredkovatel'a 10000 Kč a pre viazaného zástupcu 2000 Kč. ${ }^{22}$ Zápis sprostredkovatel’a do registru bude časovo ohraničený, a to do konca roku nasledujúceho po zápise. Na základe znenia $§ 16$ ods. 11 zákona č. 186/2009 Z. z. v spojitosti so znením opatrenia Národnej banky Slovenska č. 19/2010 o poplatkoch za úkony NBS, poplatky súvisiace s registráciou podriadených subjektov platí navrhovatel' poplatok za návrh na zápis 30 EUR a za návrh na zmenu zápisu 20 Eur. $^{23}$

\section{Záver}

V súčasnej dobe je téma finančných sprostredkovatel'ov a poradcov vel'mi aktuálna, ale aj vel'mi citlivá. Podstata finančného sprostredkovania a finančného poradenstva v poist'ovníctve znamená, že profesionálnym prístupom a zvyšovaním svojich odborných činností pomáha poist'ovniam i klientom analyzovat' jednotlivé riziká. $\mathrm{Na}$ základe realizovaného výskumu sme prezentovali určité výhody i nevýhody legislatívnych noriem, upravujúce túto oblast'. Poukázali sme na skutočnost', že činnost' finančných sprostredkovatel'ov a finančných poradcov vyžaduje odborné znalosti, prax, kvalifikáciu a v neposlednom rade cenné skúsenosti v oblasti manažmentu.

Novela doterajšieho zákona č. 38/2004 Sb. prináša mnoho zmien a podstatne mení charakter súčasnej právnej úpravy. Nová právna norma zahŕňa zmeny, ktoré majú podl’a Ministerstva financií Českej republiky viest' $\mathrm{k}$ zjednodušeniu a sprehl'adneniu jednotlivých kategórií poist'ovacích sprostredkovatel'ov a zvýšeniu ochrany spotrebitel'a. ${ }^{24}$ Dotýka sa tiež zmien na požiadavky odbornej spôsobilosti, zadefinovania povinnosti voči klientovi, zvýšenia transparentnosti sprostredkovatel'a, ale aj produktu samotného. Na základe realizovanej

\footnotetext{
${ }^{21}$ MINISTERSTVO FINANCÍ ČR. 2012. Důvodová zpráva: Závěrečná zpráva z hodnoceni dopadů regulace podle obecných zásad (RIA). [online]. [citované 2013-05-14]. 2012. Dostupné na: http://www.vlada.cz/assets/ppov/lrv/ria/databaze/Zaverecna-zprava-RIA_2.doc.

22 Tamtiež.

23 NBS. 2013. Poplatky súvisiace s registráciou podriadených subjektov. [online]. [cit. 2013-05-16]. 2013. Dostupné na internete: http://www.nbs.sk/sk/dohlad-nad-financnym-trhom/dohlad-nad-financnymsprostredkovanim-a-financnym-poradenstvom/poplatky-a-prispevky/poplatky-suvisiace-s-registracioupodriadenych-subjektov.

${ }_{24}$ ČAP. 2012. Česká asociace pojištoven: Jaké změny čekají zprostředkovatele? [online]. [cit. 2014-05-13]. 2012. Dostupné na internete: http:/www.opojisteni.cz/ekonomika/ceska-asociace-pojistoven-jake-zmenycekaji-zprostredkovatele/.
} 
komparácie možno pozorovat' mnohé odlišné, ale aj zhodné znaky legislatívy v Českej republike a v Slovenskej republike.

Novelizovaný zákon č. 38/2004 Sb. spôsobil v Českej republike rôzne diskusie „o nabízení a zprostředkování pojištění a zajištění, samostatných likvidátorech pojistných událostí a o změně živnostenského zákona (zákon o distribuci $v$ pojišt'ovnictví)“. Z prieskumu „Insurance Banana Skins“25 vyplýva, že medzi najväčšie hrozby pre české poist’ovníctvo patria nekalé podnikatel'ské praktiky. Sprostredkovatel'ské praktiky pri predaji poistenia predstavujú v Českej republike dlhoročný problém, obzvlášt' v životnom poistení. Časté prepoist'ovanie poistných zmlúv, za ktorým stoja niektorí sprostredkovatelia, nie je výhodné ani pre poist'ovňu, ani pre klienta. ${ }^{26}$ Tieto skutočností spochybňujú účinnost' novely zákona, avšak neustále sa hl'adajú kompromisné riešenia pre odstránenie týchto nedostatkov a dosiahnutie určitého konzensu.

Záverom môžeme konštatovat', že napriek tomu, že služby finančných sprostredkovatel'ov a finančných poradcov sa dnes využívajú čoraz viac, sú na kvalitu ich činnosti kladené stále vyššie a vyššie požiadavky a nároky, nielen vzhl'adom na rastúcu konkurenciu na poistnom trhu, ale aj vzhl'adom zmeny v právnych normách.

\section{Pod'akovanie}

Tento článok vznikol za podpory projektu MŠ SR VEGA č. 1/0681/12 "Ekonomické prostredie a dynamika zmien $\mathrm{v}$ sektore poist'ovníctva" riešeného na Katedre poistovníctva NHF EU v Bratislave.

\section{Literatúra}

[1] COSINAMO, T. F., 1996. Intermediation. Economica, New Series, 63(249), s. 131-143. ISSN 1468-0335.

[2] COSINAMO, T. F. and M. BAYE, 1990. In: T. F. COSINAMO, 1996. Intermediation. Economica, New Series, 63(249), s. 131-143. ISSN 1468-0335.

[3] ČAP, 2012. Jaké změny čekají zprostředkovatele? Česká asociace pojištoven [online]. [cit. 2013-02-23]. Dostupné z: http://www.opojisteni.cz/ekonomika/ceska-asociacepojistoven-jake-zmeny-cekaji-zprostredkovatele/

[4] ČNB, 2011. Výroční zpráva 2010. ČNB [online]. [cit.2013-02-23]. Dostupné z: http://www.cnb.cz/miranda2/export/sites/www.cnb.cz/cs/o_cnb/hospodareni/vyrocni_zpr avy/download/vyrocni_zprava_2010.pdf. ISBN 978-80-87225-29-5.

[5] DRAPER, D. W. and J. W. HOAG, 1978. Financial Intermediation and the Theory of Agency. The Journal of Financial and Quantitative Analysis, Proceedings of Thirteenth Annual Conference of the Western Finance Association, 13(4), s. 595-611. ISSN 00221090.

[6] DUCHÁČKOVÁ, E. 2005. Principy pojištění a pojištovnictví. Praha: Ekopress, s.r.o. ISBN 80-86119-92-0.

\footnotetext{
${ }^{25}$ Výsledky prieskumu „Insurance Banana Skins“ prevedeného Centrom pre výskum finančných inovácii (CSFI) v spolupráci s PwC (PricewaterhouseCoopers), ktorý každé dva roky sleduje najväčšie riziká pre poistovne $\mathrm{v}$ Českej republike

${ }^{26}$ PwC. 2013. Největší hrozbou pro české pojištovnictví jsou obchodní praktiky některých prodejců a přemíra regulace. [online]. [cit.2014-05-13]. 2013. Dostupné na internete: https://www.pwc.com/cz/cs/tiskovezpravy/2012/insurance-banana-skins-2013.jhtml?WT.mc_id=hp-main-3.
} 
[7] ECKARDT, M. 2007. Insurance intermediation: economic analysis of the information services market. Heidelberg: Physica-Verlag A Springer Company. ISBN 978-3-79081939-7. ISSN 1431-1933.

[8] KOMISE PRO HODNOCENÍ DOPADU REGULACE, 2012. Stanovisko komise pro hodnocení dopadů regulace $\mathrm{k}$ návrhu zákona, kterým se mění zákon č. 38/2004 Sb., o pojišt'ovacích zprostředkovatelích a samostatných likvidátorech pojistných událostí a o změně živnostenského zákona (zákon o pojištovacích zprostředkovatelích a likvidátorech pojistných událostí), ve znění pozdějších předpisů, a další související zákony. Vláda ČR [online]. [cit. 2013-03-10]. Praha: 2012. Dostupné z: http://www.vlada.cz/assets/ppov/lrv/ria/databaze/781_11_MF-Navrh-stanoviska-kzakonu-o-pojistovacich-zprostredkovatelich.pdf

[9] LIPPMAN, S. A. and J. J. MCCALL, 1986. An operational measure of liquidity. American Economic Review, 76, 43-55. ISSN 0002-8282.

[10] MAYER, C. and X. VIVES, 1993. Capital markets and financial intermediation. Cambridge: Cambridge University Press. ISBN 9780521443975.

[11] MINISTERSTVO FINANCÍ ČR, 2012. Důvodová zpráva: Závěrečná zpráva z hodnocení dopadů regulace podle obecných zásad (RIA). $M F \check{C} R$ [online]. [cit. 201305-13]. Dostupné z: http://www.vlada.cz/assets/ppov/lrv/ria/databaze/Zaverecna-zpravaRIA_2.doc.

[12] Návrh novely, ktorým sa mení zákon č. 38/2004 Sb. o pojišt’ovacích zprostředkovatelích a samostatných likvidátorech pojistných událostí a o změně živnostenského zákona (zákon o pojišt'ovacích zprostředkovatelích a likvidátorech pojistných událostí), ve znění pozdějších předpisů, a další související zákony.

[13] NBS, 2011. Dohl'ad nad finančným sprostredkovaním a finančným poradenstvom. NBS [online]. [cit. 2013-05-12]. Dostupné z: http://www.nbs.sk/sk/dohlad-nad-financnymtrhom/dohlad-nad-financnym-sprostredkovanim-a-financnym-poradenstvom.

[14] NBS, 2011. Kategórie finančných agentov a stupne odbornej spôsobilosti. NBS [online]. [citované 2013-06-10]. Dostupné z: http://www.nbs.sk/sk/dohlad-nad-financnymtrhom/dohlad-nad-financnym-sprostredkovanim-a-financnym-poradenstvom/odbornasposobilost/kategorie-financnych-agentov-a-stupne-odbornej-sposobilosti.

[15] NBS, 2013. Poplatky súvisiace s registráciou podriadených subjektov. NBS [online]. [cit. 2013-05-16]. Dostupné z: http://www.nbs.sk/sk/dohlad-nad-financnymtrhom/dohlad-nad-financnym-sprostredkovanim-a-financnym-poradenstvom/poplatky-a rispevky/poplatky-suvisiace-s-registraciou-podriadenych-subjektov

[16] Opojištění.cz, 2013. Novela zákona 38 prošla prvním čtením. Opojištění.cz [online]. [cit. 2013-02-23]. Dostupné z: http://www.opojisteni.cz/ekonomika/novela-zakona-38prosla-prvnim-ctenim/

[17] PwC. 2013. Největší hrozbou pro české pojištovnictví jsou obchodní praktiky některých prodejců a př̀míra regulace. PricewaterhouseCoopers [online]. [cit.2014-05-13]. Dostupné z: https://www.pwc.com/cz/cs/tiskove-zpravy/2012/insurance-banana-skins2013.jhtml?WT.mc_id=hp-main-3

[18] ŠKRINIAR, P., 2010. Trh jednoznačne potrebuje jednotné pravidlá. Investor, 11(7-8), s. 8-10. ISSN 1335-8235.

[19] Zákon č. 38/2004 Sb. zo 17. decembra 2003 o pojišt'ovacích zprostředkovatelích a samostatných likvidátorech pojistných událostí a o změně živnostenského zákona (zákon 
o pojišstovacích zprostředkovatelích a likvidátorech pojistných událostí). Česká Národní Banka [online]. [cit. 2013-04-11]. Dostupné z: http://www.cnb.cz/miranda2/ export/sites/www.cnb.cz/cs/legislativa/zakony/download/zakon_38_2004.pdf

[20] Zákon č. 186/2009 Z. z. z 24. apríla 2009 o finančnom sprostredkovaní a finančnom poradenstve a o zmene a doplnení niektorých zákonov. Národná Banka Slovenska [online]. [cit. 2013-04-10]. Dostupné z: http://www.nbs.sk/_img/ Documents/_Legislativa/_UplneZneniaZakonov/Z1862009.pdf

[21] Zákon č. 277/2009 Sb. o pojišt'ovnictví a o změně některých souvisejících zákonů zo dňa 22. júl 2009. Portál verejnej správy [online]. [cit. 2013-05-12]. Dostupné z: http://portal.gov.cz/app/zakony/zakon.jsp?page=0\&nr=277 2F2009\&rpp=15\#seznam

[22] Zákon č. 340/2005 Z. z. z 23. júna 2005 o sprostredkovaní poistenia a sprostredkovaní zaistenia a o zmene a doplnení niektorých zákonov. Národná Banka Slovenska [online]. [cit. 2013-04-10]. Dostupné z: http://www.nbs.sk/_img/Documents/zaklnbs/legislat/ z3402005.pdf

[23] Zákon č. 363/1999 Sb. o pojišt’ovnictví a o změně některých souvisejících zákonů ze dne 21. decembra 1999. Portál verejnej správy [online]. [cit. 2013-05-12]. Dostupné z: http://portal.gov.cz/app/zakony/zakon.jsp?page=0\&nr=363 2F1999\&rpp=15\#seznam 